\title{
Microbial Exopolysaccharides in Traditional Mexican Fermented Beverages
}

\author{
Martha L. Cázares-Vásquez ${ }^{1}$, Raúl Rodríguez-Herrera ${ }^{1}$, Cristóbal N. Aguilar-González ${ }^{1}$ (D), \\ Aidé Sáenz-Galindo $^{2} \mathbb{D}$, José Fernando Solanilla-Duque ${ }^{3}{ }^{\mathbb{D}}$, Juan Carlos Contreras-Esquivel ${ }^{1}$ \\ and Adriana C. Flores-Gallegos $1, * \mathbb{C}$
}

1 Food Research Department, School of Chemistry, Universidad Autónoma de Coahuila, Boulevard Venustiano Carranza and Ing. José Cárdenas Valdés s/n Colonia República Saltillo, Saltillo 25280, Mexico; marthacazares@uadec.edu.mx (M.L.C.-V.); raul.rodriguez@uadec.edu.mx (R.R.-H.); cristobal.aguilar@uadec.edu.mx (C.N.A.-G.); carlos.contreras@uadec.edu.mx (J.C.C.-E.)

2 Organic Chemistry Department, School of Chemistry, Universidad Autónoma de Coahuila, Boulevard Venustiano Carranza and Ing. José Cárdenas Valdés s/n Colonia República Saltillo, Saltillo 25280, Mexico; aidesaenz@uadec.edu.mx

3 Agroindustrial Engineering Department, School of Agrarian Sciencies, Universidad del Cauca, Popayán 190002, Colombia; jsolanilla@unicauca.edu.co

* Correspondence: carolinaflores@uadec.edu.mx

check for updates

Citation: Cázares-Vásquez, M.L.;

Rodríguez-Herrera, R.;

Aguilar-González, C.N.;

Sáenz-Galindo, A.; Solanilla-Duque,

J.F.; Contreras-Esquivel, J.C.;

Flores-Gallegos, A.C. Microbial

Exopolysaccharides in Traditional

Mexican Fermented Beverages.

Fermentation 2021, 7, 249.

https://doi.org/10.3390/

fermentation7040249

Academic Editors: Chih Yao Hou, Bao-Hong Lee and Ming-Kuei Shih

Received: 1 August 2021

Accepted: 27 October 2021

Published: 30 October 2021

Publisher's Note: MDPI stays neutral with regard to jurisdictional claims in published maps and institutional affiliations.

Copyright: (c) 2021 by the authors. Licensee MDPI, Basel, Switzerland. This article is an open access article distributed under the terms and conditions of the Creative Commons Attribution (CC BY) license (https:/ / creativecommons.org/licenses/by/ $4.0 /)$.

\begin{abstract}
Exopolysaccharides (EPS) are biopolymers produced by many microorganisms, including some species of the genus Acetobacter, Bacillus, Fructobacillus, Leuconostoc, Lactobacillus, Lactiplantibacillus, Pediococcus, Pichia, Rhodotorula, Saccharomycodes, Schizosaccharomyces, and Sphingomonas, which have been reported in the microbiota of traditional fermented beverages. Dextran, levan, glucan, gellan, and cellulose, among others, are EPS produced by these genera. Extracellular biopolymers are responsible for contributing to specific characteristics to fermented products, such as modifying their organoleptic properties or contributing to biological activities. However, EPS can be easily found in the dairy industry, where they affect rheological properties in products such as yogurt or cheese, among others. Over the years, LAB has been recognized as good starter strains in spontaneous fermentation, as they can contribute beneficial properties to the final product in conjunction with yeasts. To the best our knowledge, several articles have reported that the EPS produced by LAB and yeasts possess many both biological and technological properties that can be influenced by many factors in which fermentation occurs. Therefore, this review presents traditional Mexican fermented beverages (tavern, tuba, sotol, and aguamiel) and relates them to the microbial EPS, which affect biological and techno-functional activities.
\end{abstract}

Keywords: exopolysaccharide; fermented beverage; lactic acid bacteria; rheological properties

\section{Introduction}

Currently, many microorganisms such as bacteria, yeasts, fungi, and algae are well known for producing exopolysaccharides (EPS); in nature, these biopolymers affect protection, adhesion, and biofilm formation to the microorganism, helping it to adapt and survive in the environment in which it proliferates. This biofilm consists of a population of microbial cells that exhibit better resistance against nutrient reduction, temperature, $\mathrm{pH}$ changes, the effect of reactive oxygen by-products (superoxide anion radical, among others), antiseptics, and antibiotics compared to individual microbial cells [1,2]. Thus, EPS produced by microorganisms are important because of their functional and biological properties. Nevertheless, the EPS synthesized by lactic acid bacteria (LAB) are prominent within the food, cosmetic, and pharmaceutical industries due to consumer demand [3] since a large number of species of this genus have the tag "Generally Recognized as Safe" (GRAS), according to the U.S. Food and Drug Administration (FDA), where Carnobacterium, Lactococcus, Leuconostoc, Oenococcus, Pediococcus, Streptococcus, and Lactobacillus can 
be found [4]. Furthermore, LAB EPS have been associated with improving the physical properties of fermented food products, such as the texture, mouthfeel perception, and stability of fermented products $[5,6]$.

For example, the commercial use of EPSs from LAB in fermented dairy foods has conventionally been aimed at producing unique physical characteristics such as enhanced viscosity and water-binding; the result is that the consumer enjoys an improved "mouthfeel". Consumers have been attracted to smooth and creamy textures, which are conventionally achieved by adding fats, sugars, and proteins [7]. Several articles have reported EPS with potential health and nutritional benefits resulting from LAB. These EPS have also been associated with different biological properties, such as anti-tumoral, anti-hypertensive, anti-ulcer, immunomodulating, or cholesterol-lowering activity $[5,7]$.

Although the literature has considered the EPS produced by LAB to be the most important, this review is not intended to focus only on them but rather on all of the microorganisms found within the fermentation process of traditional Mexican fermented beverages, which are presented in this document, and how some of these are related to their biological and technological properties.

\section{Exopolysaccharides}

Exopolysaccharides (EPSs) are produced by many LAB species [8-10]. They are a polymer of carbohydrates that form a slimy, loosely attached layer around the bacterial cell but that can be exuded into the surrounding environment after growth. EPSs are a diverse group of long-chain, high-molecular-mass polysaccharides (ranging from $10^{3}$ to $10^{7} \mathrm{Da}$ ) consisting of branched, repeating units of sugar, substituted sugars, or derivatives of sugars as well as other substituents such as phosphate and acetyl groups [11]. The sugar units are most commonly glucose, galactose, and rhamnose and are found in different ratios of individual sugar monomers. EPS vary in their composition and physicochemical characteristics [12,13]. This variation depends on several factors, such as culture medium composition, carbon, and nitrogen sources (influence the production and concentration of EPS), mineral salts, trace elements, type of strain, and fermentation conditions ( $\mathrm{pH}$, temperature, oxygen concentration, agitation, etc.) [5,14]. EPS can be classified into two big groups: homopolysaccharides (HOPS) and heteropolysaccharides (HEPS). Typically, LAB produce HEPS, which have dissimilar monosaccharide units linked together at different positions to form multiple copies of "oligo-units" that are between three and eight monomers in length. The result of these combinations is structures that vary compositionally, structurally, and in size. These HEPS are between $4 \times 10^{4}$ and $6 \times 10^{6} \mathrm{Da}$ in size and vary in the volume of space that they occupy. The HEPS are secreted to the exterior of the cell and for either a capsular EPS (attached to the cell) or are released unattached into the surrounding medium (or both), generating, in most instances, a ropy characteristic [7,12]. HEPS comprise different varieties of monosaccharides, such as D-glucose, D-galactose, L-rhamnose, and their derivatives. Major representative HEPS types are produced by mesophilic and thermophilic lactic acid bacteria, including L. lactis subsp. lactis, L. rhamnosus, L. lactis subsp. cremoris, L. sakei, L. casei whereas L. delbrueckii subsp. bulgaricus, L. acidophilus, L. helveticus, and S. thermophiles [15]. On the other hand, HOPS are polymers of a single monosaccharide, usually either glucose or fructose, and are termed glucans or fructans, respectively. HOPS are produced by several LAB genera, including Lactobacillus, Streptococcus, Leuconostoc, Oenococcus, and Weissella. HOPS can be divided into four sub-groups, including (1) $\alpha$-D-glucans, which is produced by L. mesenteroides subsp. mesenteroides and subsp. dextranicum and S. sobrinus, which are composed of $\alpha-1,6$ and $\alpha-1,3$ linked glucose molecules with variable degrees of branching at position 3 ; however, they may also be present at position 2 or 4 ; (2) $\beta$-D-glucans, produced by Pediococcus and Streptococcus, which is composed of glucose molecules linked to the $\beta-1,3$ residual position along with $\beta-1,2$ branching species; (3) fructans, produced by Streptococcus salivarius, which are linked to $\beta$-fructose molecules at the $\beta-2,6$ residual position along with $\beta-2,1$-branching on the O1 site; and finally, (4) poly-galactan, which is composed of repeating sugar units 
that are identical in terms of their chemical structures and are linked together with different glycosidic bonds $[13,15]$. The different types of EPS are illustrated in Figure 1.

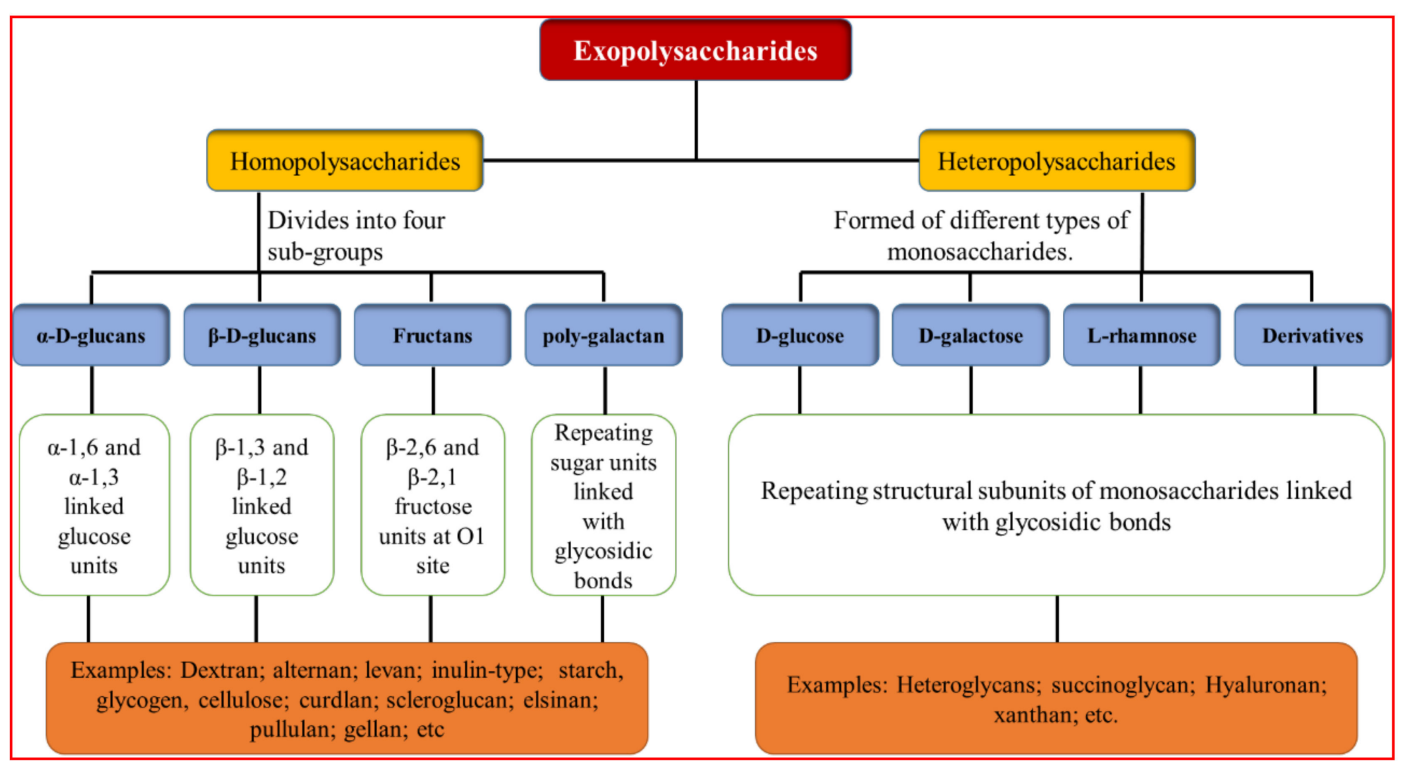

Figure 1. Classification of EPS [15].

The EPS synthesis is conducted by a broad spectrum of enzymes that are not specific or unique to EPS production [16]. Depending on the polymer that is secreted, this synthesis can occur either outside the cell or within the cell wall. However, this can be divided into three major steps (Figure 2): (1) carbon source assimilation and the synthesis of the EPS precursor, (2) the biosynthesis of repeating units (polymerization), and (3) secretion out of the cell (exportation) [16-19].

In the first step, the conversion of the carbon source into the EPS precursor begins. This happens in the cytoplasm, where the substrate is catabolized through glycolysis, and the primary metabolites that are formed are used as precursors for synthesizing small biomolecules. The synthesis of polysaccharides requires the biosynthesis of activated precursors that are rich in energy, such as monosaccharides and diphosphate sugars, which are mainly nucleosides derived from phosphorylated sugars; for each type of polymer, such as dextran, xanthan, etc., specific precursors and enzymes participate in their synthesis. For example, uridine diphosphate (UDP)-glucose is the direct cellulose synthesis precursor seen by Acetobacter xylinum [17]. In the second step, highly specific sugar transferase enzymes (glycosyltransferases) facilitate the transfer of sugar nucleotides, monosaccharides, and acyl groups to the isoprenoid lipid acceptors located in the cytoplasmic membrane, creating EPS repeating units. Next, the repeating oligosaccharide units are polymerized to long-chain by polymerases with acetyl, pyruvyl, and other compounds. After the polymerization of the repeat units, the polysaccharide is excreted through the outer cytoplasmic membrane, which is possibly coordinated by the formation of a multi-protein complex involving cytoplasmic, outer membrane, and periplasmic proteins (flippases); the chain length can be modified by an enzyme that can separate the lipid-bound polymer $[17,19]$. The last step concludes with the secretion of the EPS. Polysaccharides are polymerized in the cytoplasmic membrane and are then exported through a lipid transporter: long-chain phosphate esters and isoprenoid alcohols from the cytoplasmic membrane. To conclude, it should be noted that these steps may vary depending on the carbon source, the microorganism that produces it, and the class of the polymer [17]. 

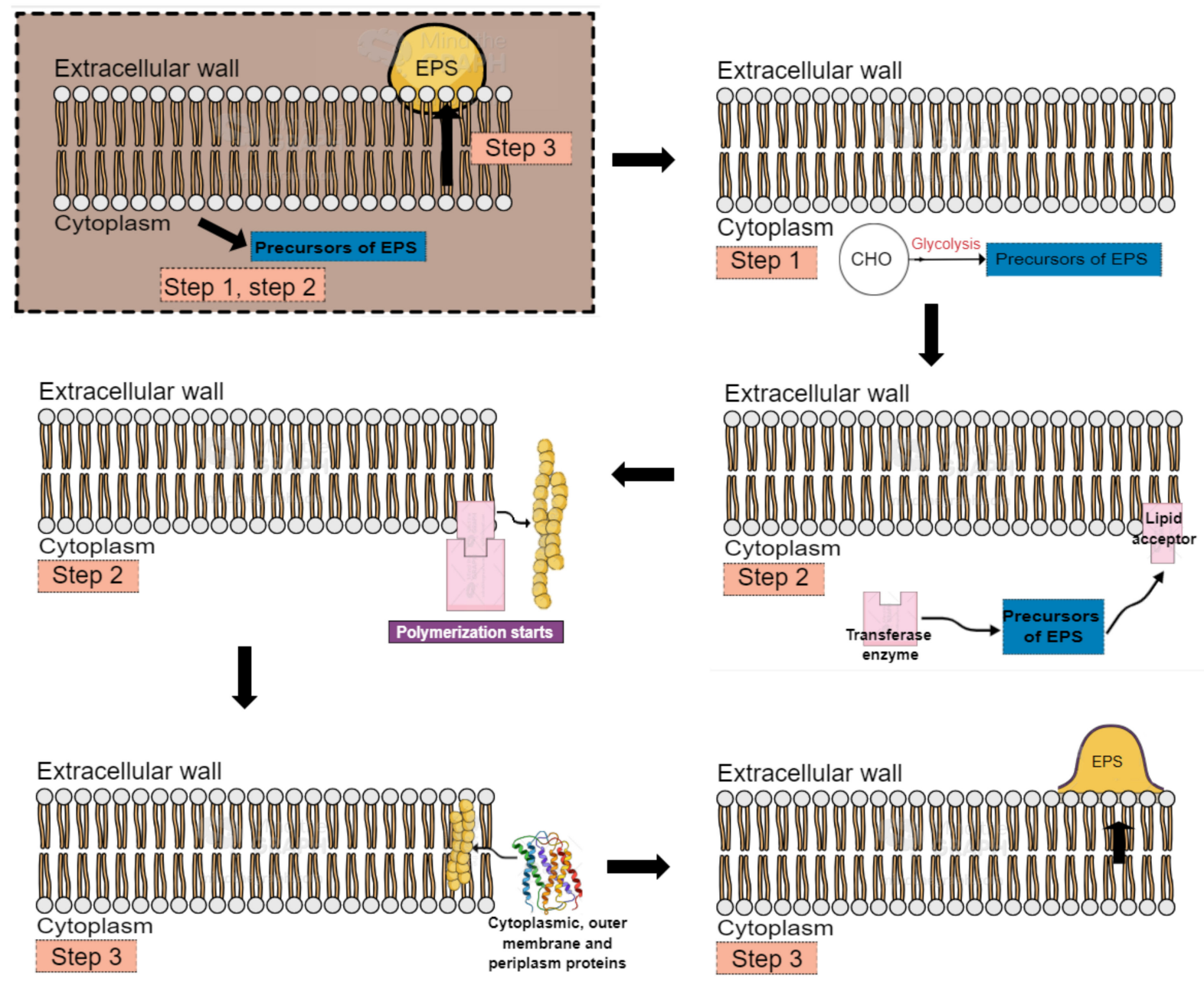

Figure 2. Scheme of exopolysaccharides (EPS) synthesis [16-19].

\section{Microbial EPS in Traditionally Fermented Regional Beverages}

\subsection{Tavern}

According to a report by Coutiño et al., tavern is an alcoholic beverage derived from the fermentation process of Acrocomia aculeata palm sap. This drink is locally produced in some Mexican states: Colima, Sinaloa, Oaxaca, Veracruz, and Chiapas. In Chiapas, this beverage is specifically produced by the Mayans and is used in cultural rituals. However, tavern is not the only fermented drink that is produced from palm sap. Among others, different palm species produce different fermented beverages, such as tuba, ogorogoro, chicha, and mimbo [20].

Tavern is very sweet, which favors microbial metabolic activity, thus allowing the fermentation process to be conducted and, over the course of this fermentation process, contributing to specific characteristics to this drink [21]. According to Santiago-Urbina et al., this drink has an initial composition of different carbohydrates $(w / v)$, such as sucrose in a ratio of $11.36 \%$, fructose in a ratio of $0.27 \%$, and glucose in a ratio of $0.23 \%$ as well as an initial $\mathrm{pH}$ of $7.26 \pm 0.2$, which decreases to values of 4 during the fermentation process. Carbohydrate content varies since the palm is constantly producing sap used by microorganisms during fermentation, yielding levels of $0.58(\%, w / v)$ [22]. Other studies point to the protein content present in coyol or tavern wine, where this beverage derived from palms located in mountainous places has a content of $0.033 \mathrm{~g} / \mathrm{L}$, while tavern from palms located in the valley has a content of $0.028 \mathrm{~g} / \mathrm{L}$. The protein content is essential for the development of the natural microbiota. It has also been found that the content of reducing sugars present in this fermented drink ranges from 5.84 to $9.22 \mathrm{~g} / \mathrm{L}$ in mountainous palms 
and from 4.49 to $9.14 \mathrm{~g} / \mathrm{L}$ in the valley palms. As mentioned above, sugar consumption varies; these sugars are not consumed entirely, providing a characteristic sweet flavor at the end of fermentation [21].

The ${ }^{\circ}$ Brix ranges from 17.36-19.4, indicating a high level of total soluble solids, where sucrose is found in the highest proportions. The ethanol content is another important tavern physical property since it can reach percentages of 7.06 to $10.31 \%$; acetic acid production can reach concentrations of $0.17-2.11 \%$; and propionic acid can reach concentrations of $0.017-0.020 \%$. Finally, it is important to note that tavern's physicochemical composition depends on the presence of microorganisms, collection time (morning, afternoon, or night), temperature, and soil topography, among other factors [20].

Tavern or coyol wine is a fermented drink with several beneficial properties for human health, such as alleviating gastrointestinal diseases such as gastritis, ulcers, and constipation. Previous studies have reported many microorganisms growing in tavern: Schizosaccharomyces pombe, Arthroascus spp, Hanseniaspora uctum, Kloeckera spp Fructilactobacillus fructosus, Zymomonas mobilis, Gluconobacter oxydans, Gluconactetobacter saccharivorans, Limosilactobacillus fermentum, and Liquorilactobacillus sucicola. Species from the Saccharomyces, Candida, Pichia, and Acetobacter genera have also been found [20,23]; a detailed description of the microbiota in tavern is given in Table 1. Fructilactobacillus fructosus has been reported as an EPS producer; nevertheless, these polysaccharides have not been reported yet. Next, Kodamaea ohmerii has also been reported for EPS production; isolated from the kéfir grain, its EPS have been demonstrated to have an inhibitory effect on rotavirus, although this has not been identified [24]. Saccharomycodes ludwigii has also been found to produce extracellular polysaccharides, which were revealed to essentially be mannoproteins with a high mannose content, ranging from 93\%; Schizosaccharomyces pombe has been reported as a non-identified EPS with the presence of galactose, mannose, and glucose [25]. Z. mobilis stands out in the production of tavern, representing an approximately $60-80 \%$ proportion of the bacterial community due to their ability to grow under acidic conditions; the presence of level has been reported in this strain $[20,23]$. On the other hand, some lactic acid bacteria (LAB) are easily proliferated within the sap. The optimal $\mathrm{pH}$ and temperature at which this bacteria genus grows are 3.8 and 7.2 and $35-40{ }^{\circ} \mathrm{C}$, respectively [20]. Moreover, this palm sap suffers a natural fermentation, which contributes to the proliferation of microorganisms. The presence of microorganisms with a prebiotic effect has also been reported, including the presence of L. mesenteroides, which is present in the final stages of the fermentation process. This strain, which is categorized as a dextran producer and HEP with monomers such as glucan and mannose, has demonstrated cellular adhesion, automatic aggregation properties, and hydrophobicity, which are confirmatory in its ability to adhere and colonize the intestine. Likewise, Limosilactobacillus fermentum, in addition to being capable of producing short-chain fatty acids, possesses good antioxidant activity [20]. It has also been reported as a prebiotic organism since it improves gastrointestinal transit tolerance due to EPS production. This species produces three different EPSs; the first corresponds to the homopolysaccharide (HOP) of an Mw of $400 \mathrm{kDa}$ and two different low molecular weight HEPS of less than $2 \mathrm{kDa}$. HOP is composed of repeating units of D-glucose linked by an $\alpha$-1,4-glycosidic bond, where $20 \%$ of the glucose subunits is acetylated at C- 3 . In another study, Wang et al. isolated L. fermentum from traditional fermented Fuyuan pickle, where three purified EPS were extracted. All of them were composed of glucose, galactose, mannose, and arabinose with an Mw of $4.45 \times 10^{6}$, and $2.82 \times 10^{6} \mathrm{Da}$. Limosilactobacillus fermentum EPS have also shown favorable anti-biofilm activity against pathogens [26]. This type of bacteria provides biological effects since they have an anti-inflammatory effect. It is important to note that the microbial presence or absence in tavern depends on different conditions, such as temperature. 
Table 1. Species of the bacteria and yeast in tavern [20,27-32].

\begin{tabular}{ccc}
\hline Acetobacter & Saccharomyces & Other Microorganisms \\
\hline A. tropicalis & S. cerevisiae & Cyberlindnera jadinii \\
A. estunensis & S. chevalieri & Kodamaea ohmeri \\
A. aceti & S. bayanus & Meyerozyma guilliermondii \\
A. lovaniensis & S. uvarum & Millerozyma farinosa \\
& & Saccharomycodes ludwigii \\
Pichia & Candida & Wickerhamiella paraugosa \\
P. membranifaciens & C. tropicalis & Zygosaccharomyces bailii \\
P. kudriavzevii & C. parapsilosis & \\
\hline
\end{tabular}

\subsection{Tuba}

Similar to tavern, tuba is a beverage that comes from the fermentation process of sap from Cocus nucifera palms. The tradition of ingesting this drink comes from Asia, specifically from the Philippines. Commonly, this nectar is consumed in the Mexican Pacific region, specifically in Colima, Michoacán, Jalisco, and Guerrero. tuba is also known as "nectar" or "honey water" in the Mexican Republic; "Neera" in India, "Toddy" in the Philippines; and "Tuak" in Indonesia. Usually, this beverage is obtained by dripping the sap from the stem or the inflorescences of the coconut palm. Its composition can vary depending on the place, time, and duration of the tapping. Still, it commonly has a sugar content of $10-15 \%$, which makes it susceptible to spontaneous fermentation, where lactic acid fermentation occurs first follow by alcoholic fermentation, where the $5-8 \%$ of the sugars are converted into alcohol. Finally, acetic fermentation occurs; here, coconut vinegar is produced, which contains a percentage of $4-7 \%$ acetic acid [33].

Different isolated yeasts and bacteria have been reported when obtaining tuba. Some authors report other lactic acid bacteria (LAB) and acetic acid bacteria (AAB) genera [34]. This microbial diversity is obtained from sources such as the palm stem, inflorescence, attracted insects, and materials used in the recollection. In addition to conferring the typical organoleptic characteristics of this beverage, it has been found that both types of microorganisms start the fermentation process during tuba production. The dominant species reported by Flores-Gallegos et al. [28] are Saccharomyces chevalieri, S. cerevisiae; Saccharomycodes ludwigii, Schizosaccharomyces pombe, Kluyveromyces marxianus, Lachancea fermentati, Kloechera apiculata, Candida glabrata, Pichia anghophorae, and Meyerozyma caribbica, which are present in yeasts.

It should be noted that Sphingomonas can produce EPS from S. paucimobilis, which corresponds to a gellan; it is a heteropolymer that contains glucose, rhamnose, and glucuronic acid. This EPS has high potential for use in the pharmaceutical and food industries; however, Candida has also been found. Yeasts and LABs use the sugars present in the sap as a substrate to produce alcohol as well as for the production of lactic acid; the alcohol that is produced will serve as a substrate for AABs to generate acetaldehyde and acetic acid and is the main volatile acid in palm wine.

The natural fermentation process of coconut nectar is known to have three steps: first, the initial lactic acid fermentation, where S. pombe ferments glucose and sucrose; then, the medium alcoholic fermentation; and finally, acetic acid fermentation, where P. angophorae ferments sucrose and where K. apiculata and C. glabrata ferment fructose and galactose [35]. The LAB predominates at the beginning of this fermentation process, usually between the third and ninth hour. After that time, at the eleventh hour, the yeasts reach their maximum point. LAB play an essential role in the fermentation and preservation of the drink, while the $\mathrm{AAB}$ intervene in the development of the vinegar flavor. Bacillus (B. cereus synthesize levan with two Mw of $568.000 \mathrm{Da}$ and $<50.000 \mathrm{Da}$ [36]), Enterobacter, Leuconostoc, Micrococcus, and Lactobacillus are among the bacteria genera that have been reported. It is worth mentioning that the LAB genera that stand out are Fructilactobacillus fructosus, whose presence has already been detected in EPS but has not yet been not identified [37] and Lactiplantibacillus plantarum, Fructobacillus durionis, Leuconostoc 
mesenteroides, and Pediococcus, which are species of $P$. pentosaceus that produce a complex of extracellular polysaccharides with an Mw of about $2000 \mathrm{kDa}$ and are composed of glucose and fructose. Particularly, the species of L. plantarum have been reported because of their production of glucan with an Mw of $94 \mathrm{kDa}$, which has antibacterial, anticoagulant, and fibrinolytic activity [38]. The production of an EPS consisting of xylose, glucose, and galactose with an Mw $6.61 \times 10^{4}$ [39] and an EPS consisting of arabinose, rhamnose, fucose, xylose, mannose, fructose, galactose, and glucose with an Mw of $12.4 \mathrm{kDa}$ have also been reported [40]; L. mesenteroides are attributed to the rapid acidification that the sap presents. The latter refers to L. mesenteroides, which can also be attributed to EPS production since it produces dextran from sucrose. However, more EPS have been reported, such as HEPS, which contains monomers such as glucan and mannose with Mw values of $2.0 \times 10^{5} \mathrm{Da}$; the viscosity of this beverage can be attributed due to the presence of these bacterial polymers. Moreover, L. mesenteroides EPS possess a heat resistance of $80^{\circ} \mathrm{C}$, an excellent emulsification effect, and the literature indicates that this EPS could scavenge superoxide anion free radicals, suggesting its potential usage as a food additive [28,41].

AABs are divided into the genera of Acetobacter, where acetan EPS has been produced by A. xylinum, Acidomonas, Gluconobacter, and Gluconacteobacter. The Gluconacetobacter genus has also reported the presence of cellulose with a large Mw when galactose served as a sole carbon source; this EPS is synthesized by G. xylinus [42]. AAB genera are generally in the final stage of the fermentation process. The Acetobacter genus prefers alcohol as a carbon source, while Gluconobacter oxidizes ethanol to produce acetic acid. This genus also ferments arabinose, xylose, ribose, glucose, galactose, mannose, and melibiose but does not ferment sucrose [33].

\subsection{Sotol}

According to Flores-Gallegos et al. [33], sotol is a distilled alcoholic beverage that is obtained from the spontaneous fermentation process of the plant of the same name. Sotol grows in arid regions, is generally found in the northern part of Mexico, and has been used as a food medicine source for more than 7000 years. Its long leaves range from pale gray to pale green, forming a rosette at the base (0.80-1.3 $\mathrm{m}$ long and 2-3.5 cm wide). After the first 3.5 years of life, the sotol leaves begin to dry. However, they will continue to be attached to the stem when they dry completely since this helps prevent excessive water loss. This allows different types of microorganisms to grow, such as bacteria, fungi, and yeasts. A long time ago, it was believed that the sotol and agave plants were related. Still, in 1990, with the help of molecular tools, it was classified as follows: phylum: Spermatophyta; division: Anthophyta; class: Angiospermae; order: Liliales; series: Choripelalae; family: Nolinaceae; genus: Dasylirion. The Dasylirion cedrosanum and Dasylirion duranguensis species are the most attractive for the production of alcoholic beverages. Sotol can be classified into four categories: silver sotol (diluted in water), gold sotol (from 1 to 2 months old), old sotol (from 2 months in oak or aracia barrels), and extra old sotol (aged at least one year in barrels).

There are very few studies where the chemical composition of this drink is indicated. Nonetheless, some authors indicate that it is constituted by many sugars such as fructose, glucose, sucrose, fructooligosaccharides, and fructosyl polymers [43], where the percentage of total sugars in female plants is $5.8 \%$ and is $6.24 \%$ for male plants; $2.98 \%$ and $4.17 \%$ for reducing sugars; $0.49 \%$ and $0.51 \%$ for proteins; $9.31 \%$ and $10.03 \%$ for fiber; $0.88 \%$ and $0.96 \%$ for ash; $0.88 \%$ and $0.65 \%$ for fats; and of $69.27 \%$ and $66.22 \%$ for humidity for female and male plants, respectively. Protein is an indicator of the biomass of the microorganisms present in fermentation. However, since the sotol manufacturing process requires a cooking step, the protein content tends to decrease after this [33].

Sotol has a high content of complex sugars such as lignocellulose (cellulose, hemicellulose and lignin), which release fermentable sugars when subjected to thermal treatments. On the sixth day of fermentation, there is a decrease in the sugar content, which can be attributed to the proliferation of microorganisms with a rapid fermentation capacity, 
such as yeasts, which use glucose molecules and other secondary nutrients to reproduce. To analyze the chemical components present in sotol liqueur, solid-gas micro-extraction chromatography can be used. The following components are commonly found in sotol: 10.6-12\% 2-methyl-1-propanol, 23.2-32.7\% 3-methyl-1-butanol, 3.7-8.0\% octanoic acid, $11.7-32.2 \%$ acetic acid, $0.6-0.88 \%$ phenylethanol, and $0.8-2.1 \%$ butyrolactone [33]. Other compounds such as ethyl acetate, propanol, 1-butanol, and 3-hydroxy butanol have been detected in the analysis of commercial sotol [43].

To obtain this distilled beverage, first, the fermentation process is necessary. The liquor is obtained by cooking the central part of sotol plants, also known as pineapples; this is previously fermented and distilled. Natural fermentation is conducted by the presence of bacteria and yeasts that act together. It should be noted that the use of yeasts is of great importance in the production of alcoholic beverages since they can produce large amounts of ethanol in addition to producing a characteristic aroma. On the other hand, bacteria, specifically LABs, are important in the process since they are related to the production of acids, compounds that confer desirable flavors and peptides that are capable of inhibiting the growth of undesirable microorganisms [33,43].

Sotol has great microbial diversity that improves the organoleptic characteristics of the drink; however, this load decreases after the cooking process. Crushing is an important step in the artisanal fermentation process. This type of solid-state fermentation is considered to achieve saccharification of polysaccharides or hydrolysis of cellulose from pineapple rinds by increasing the inoculum yeast. The wort fermentation occurs by mixing the pineapple pieces with two volumes of water; these are placed in barrels that are located at ground level. To determine the microorganisms that are present in the sotol, it is necessary to take samples from each stage of the process: in situ (inside sotol plants), raw pineapples, cooked pineapples, and crushing pineapples must have samples taken from them. During the first step, a variety of bacteria, such as Bacillus licheniformis, Bacillus subtilis, Acetobacter sp., and Bradysia difformis are included. However, during the mashing stage, the number of yeast colonies increases, and S. cerevisiae, Prototheca sp., and Candida glabrata are present as identified species. At the end of the process, only S. cerevisiae can be identified. Fermentation ends when all of the sugar is consumed [33,43]. In the different stages that have been mentioned, there are certain reports as to whether some species are EPS producers. For example, A.xylinum, which produces acetan [44], and G. xylinus, which produces celullose with large size when galactose serves as an exclusive carbon source [45], as well as B. subtilis, which synthesizes levan with two Mw of 568.000 Da and $<50.000 \mathrm{Da}[36]$.

\subsection{Aguamiel}

Aguamiel or agave sap is a product that is derived from different species of Agave such as Agave atrovirens, Agave Salmiana, Agave americana, Agave ferox, and Agave mapisaga $[46,47]$. This plant grows in Mexico's semidesert areas and is mainly used to produce pulque, an ancient beverage in the American continent [48]. This nectar is light-yellow in color and has a herbaceous odor; it is also rich in carbohydrates (glucose, sucrose, and fructose), gums, proteins, minerals, vitamins, amino acids, saponins, and phenolic compounds. Saponins and phenolic compounds have reported biological properties such as anti-inflammatory and antioxidant activity, respectively [46]. Agave sap can be consumed as a fresh, concentrated, or fermented product (pulque), and recent studies have suggested its use in the food industry as a functional beverage since prebiotic compounds such as fructooligosaccharides (FOS) [46,49] and EPS [50] have also been reported to be present in it.

The content and structure of saponins in agave are affected by the maturity stage of the agave as well as the species. In A. salmiana, it has been reported that the levels of saponins are lower in mature plants than in immature ones. Saponins are glycosylated triterpenoids and steroidal alkaloids that possess a wide variety of biological properties such as antibacterial, antifungal, and anticancer activity. Aguamiel shows good levels of antioxidant 
activity compared to coffee and grape juice. This value was reported as $904.8 \mu \mathrm{M}$ gallic acid; other reports indicate the presence of phytase activity of $0.933 \mathrm{U} / \mathrm{mL}$. This is important because phytate inhibits the absorption of minerals such as calcium and iron in cereals. In addition, nowadays, agave sap is used for ethanol and polysaccharide production (usually $\beta$-glucans and dextrans). agave sap increases the viscosity, producing non-Newtonian fluids. This property is related to dextran and levan polymers, which are considered to be great emulsificants. They are derivative from sucrose by the Leuconostoc species that are present; however, HEPS has also been reported to contain monomers such as monomers as glucan and mannose and Mw with a value of $2.0 \times 105$ Da [46]. In 2014, Torres-Rodríguez et al. found that an LAB strain identified as Companilactobacillus kimchii isolated from pulque can produce EPS. They found two phenotypically different colonies (labeled EPSA and EPSB) corresponding to the same C. kimchii strain, where the characterized EPS was dextran. Scanning electron microscopy (SEM) analysis revealed that both form a uniform porous structure that surrounds the cells. The structural characterization showed that the polymers produced by EPSA (polymers produced by the soluble and cell-associated fractions) are dextrans consisting of a linear backbone of linked $\alpha-(1 \rightarrow 6)$ Glcp in the main chain with $\alpha-(1 \rightarrow 2)$ and $\alpha-(1 \rightarrow 3)$-linked branches, while EPSB (polymer produced by the soluble fraction) was identified as a class 1 dextran with a linear backbone containing consecutive $\alpha$-(1 $\rightarrow 6)$-linked D-glucopyranosyl units with few $\alpha-(1 \rightarrow 3)$-linked branches, whereas the cell-associated EPS is a polymer mixture consisting of a levan composed of linear chains of $(2 \rightarrow 6)$ linked $\beta$-D-fructofuranosyl residues with $\beta$ - $(2 \rightarrow 6)$ connections and a class 1 dextran. They also reported the presence of dextran and levan as well as an EPS containing only one monosaccharide, glucose, with an Mw of 306,606 Da [51]. Additionally, Castro Rodríguez et al. [52] isolated an LAB strain (Leuconostoc mesenteroides) from agave sap, which was characterized an EPS identified as dextran. Dextran produced by this strain has a backbone chain of $\alpha(1 \rightarrow 6)$ linkages with $\alpha(1 \rightarrow 3)$ branching.

Agave sap fermentation occurs under non-aseptic conditions. Frequently, farmers ferment the aguamiel in plastic containers for pulque production, a traditional Mexican non-distilled alcoholic beverage that is currently consumed. This promotes the proliferation of many microorganisms such as bacteria and yeasts, including those naturally added and those added during the collection, transport, inoculation, and handling. Saccharomyces cerevisiae and species of Kluyveromyces, Leuconostoc, Lactobacillus, and Zymomona are within them, the last one being an EPS producer when paired with $Z$. mobilis species, which produces levan. These species are related to beneficial properties for human health [47]. Additionally, and agreeing with some previously mentioned genera, Villarreal-Morales et al. (2019) reported the presence of microorganisms, mainly those of Lactobacillus, Leuconostoc, Sarcina, Pseudomonas, Streptococcus, Diplobacter, Bacillus, Hansenula, Saccharomyces, Pichia, Candida, Rhodotorula, Mycoderma, and Zymomonas genera, pointing out that the main microorganisms responsible for the viscosity of the drink is due to the presence of the dextrans produced by L. mesenteroides [46].

Nowadays, specific species reporting the presence of EPS in some genres that have been mentioned by Villarreal-Morales et al. exist. First is B. subtilis, which produces levan with two Mw of 568.000 Da and <50.000 Da; the levan presents Newtonian behavior and no toxic effects [36]. Second, there are reports indicating that L. plantarum produces glucan of $94 \mathrm{kDa}$, which possess antibacterial, anticoagulant, and fibrinolytic activity [38]; it also synthesizes EPS consisting of xylose, glucose, and galactose with an Mw $6.61 \times 10^{4}$ [40] and EPS consisting of arabinose, rhamnose, fucose, xylose, mannose, fructose, galactose, and glucose with an Mw of $12.4 \mathrm{kDa}$ [40] as well as two Lactobacillus species: L. caseii, which produces a neutral heteropolysaccharide predominantly consisting of glucose (about $75 \%$ ) and rhamnose (about 15\%) [40], and L. citreum, which has been reported to produce dextran containing about $11 \% \alpha-(1-2)$ and about 3.5\% $\alpha-(1-3)$-linked branches. This EPS may be useful as a source of prebiotic glucooligosaccharides with $\alpha-(1-2)$ linked branches. There have also been reports of another dextran with an Mw $6.07 \times 10^{6}$ that is composed of 
D-glucopyranose units in a linear chain with consecutive $\alpha(1 \rightarrow 6)$ linkages. No branching was found in the structure [53].

For the Kodamaea and Pichia genera, the literature reports two species as EPS producers of K. ohmeri and P. holstii. The first one, K. ohmeri, was isolated from the kéfir grain, and its EPS were demonstrated to have an inhibitory effect on rotavirus, although the EPS have not been identified yet [24]. Then, P. holstii produces EPS composed of a phosphomannan core to which oligosaccharide diester phosphate side chains are appended [54]. Next, Rhodotorula has EPS composed of four neural monosaccharides: glucose, mannose, galactose, and fucose, with an average $\mathrm{Mw}$ of $1200 \mathrm{KDa}$. This polysaccharide is the first one to be reported to have immunomodulatory activity that is marine-derived, and it is synthesized by R. mucilaginosa [55]. Finally, the Zymomonas genera produces levan from the Z. mobilis species [56]. Table 2.

All of the fermented beverages that were mentioned in this work are summarized in

Table 2. Microbiota and related-EPS in traditional Mexican fermented beverages.

\begin{tabular}{|c|c|c|c|c|}
\hline Fermented Beverage & Microbiota & EPS & Beneficial Effects & References \\
\hline Tavern & $\begin{array}{c}\text { Acetobacter tropicalis, } \text { A. } \\
\text { estunensis, A. aceti and, A. } \\
\text { lovaniensis; Arthroascus spp; } \\
\text { Candida tropicalis and C. } \\
\text { parapsilosis; Cyberlindnera jadinii; } \\
\text { Pichia kudriavzevii; Wickerhamiella } \\
\text { paraugosa; Fructilactobacillus } \\
\text { fructosus *; Gluconobacter oxydans, } \\
\text { and Gluconacetobacter } \\
\text { saccharivorans; Hanseniaspora } \\
\text { uctum; Limosilactobacillus } \\
\text { fermentum *; Liquorilactobacillus } \\
\text { sucicola } \text {; Leuconostoc } \\
\text { mesenteroides *; Kloeckera; } \\
\text { Millerozyma farinosa; Pichia } \\
\text { membranifaciens, Kodamaea ohmeri } \\
\text { * and, Meyerozyma guilliermondii; } \\
\text { Saccharomyces cerevisiae, S. } \\
\text { bayanus, S. uvarum, and S. } \\
\text { chevalieri; Saccharomycodes } \\
\text { ludwigii*, Zygosaccharomyces } \\
\text { bailii, Schizosaccharomyces pombe } \\
\text { *; Zymomonas mobilis * }\end{array}$ & $\begin{array}{c}\text { Levan } \\
\text { Dextran } \\
\text { HOP (Mw } 400 \mathrm{kDa} \text {, composed of } \\
\text { repeating units of D-glucose) } \\
\text { HEP (Mw < } 2 \mathrm{kDa}) \\
\text { HEPs (Mw } 44,500 \text { and } 2820 \mathrm{kDa} \text {, } \\
\text { composed of glucose, galactose, } \\
\text { mannose and arabinose) } \\
\text { HEP (Mw } 200 \mathrm{kDa} \text { with the } \\
\text { presence of monomers such as } \\
\text { glucan and mannose) } \\
\text { EPS with high mannose contents } \\
\text { (93\%) } \\
\text { HEP (composed of galactose, } \\
\text { mannose and glucose) }\end{array}$ & $\begin{array}{l}\text { Antioxidant activity, } \\
\text { improves } \\
\text { gastrointestinal } \\
\text { transit tolerance, } \\
\text { antibiofilm activity } \\
\text { against pathogens, } \\
\text { great emulsification } \\
\text { effect, could } \\
\text { scavenge } \\
\text { superoxide anion } \\
\text { free radicals, and } \\
\text { inhibitory effect on } \\
\text { rotavirus }\end{array}$ & {$[20,23-27,37,41,56-61]$} \\
\hline Tuba & $\begin{array}{c}\text { Acetobacter *; Acidomonas; Bacillus } \\
\text { *; Candida glabrata; Meyerozyma } \\
\text { caribbica; Enterobacteriaceae; } \\
\text { Fructilactobacillus fructosus *, } \\
\text { Fructobacillus durionis; } \\
\text { Gluconacetobacter; Gloconobacter *; } \\
\text { Kloechera apiculata; Kluyveromyces } \\
\text { marxianus; Lactiplantibacillus } \\
\text { plantarum *; Leuconostoc } \\
\text { mesenteroides *; Micrococcus; } \\
\text { Pediococcus *; Pichia anghophorae; } \\
\text { Saccharomyces chevalieri, S. } \\
\text { cerevisiae; Saccharomycodes } \\
\text { ludwigii; Schizosaccharomyces } \\
\text { pombe; Sphingomonas *; Vibrio; } \\
\text { Lachancea fermentati }\end{array}$ & $\begin{array}{c}\text { Acetan } \\
\text { Dextran } \\
\text { Levan (Mw of } 568 \mathrm{kDa} \text { and } \\
<50 \mathrm{kDa}) \\
\text { Celullose } \\
\text { Glucan (Mw } 94 \mathrm{kDa}) \\
\text { Gellan (HEP containing glucose, } \\
\text { rhamnose, and glucuronic acid) } \\
\text { HEP (Mw } 66 \mathrm{kDa} \text {, consisting of } \\
\text { xylose, glucose, and galactose) } \\
\text { HEP (Mw } 12.4 \text { kDa consisting of } \\
\text { arabinose, rhamnose, fucose, } \\
\text { xylose, mannose, fructose, } \\
\text { galactose, and glucose) } \\
\text { HEP (Mw 2000 kDa composed of } \\
\text { glucose and fructose) } \\
\text { HEP (Mw } 20 \mathrm{kDa} \text { with the } \\
\text { presence of monomers such as } \\
\text { glucan and mannose) }\end{array}$ & $\begin{array}{l}\text { Antibacterial, } \\
\text { anticoagulant, } \\
\text { fibrinolytic activity, } \\
\text { thermophile, great } \\
\text { emulsification effect, } \\
\text { and it could } \\
\text { scavenge } \\
\text { superoxide anion } \\
\text { free radicals }\end{array}$ & {$[28,36-41,44,61-65]$} \\
\hline Sotol & $\begin{array}{c}\text { Acetobacter sp *; Bacillus } \\
\text { licheniformis, B. subtilis *; Bradysia } \\
\text { difformis; Candida glabrata; } \\
\text { Prototheca sp; Saccharomyces } \\
\text { cerevisiae }\end{array}$ & $\begin{array}{c}\text { Acetan } \\
\text { Celullose } \\
\text { Levan }(\mathrm{Mw} \text { of } 568 \mathrm{kDa} \text { and } \\
<50 \mathrm{kDa})\end{array}$ & & {$[33,36,43,44,65]$} \\
\hline
\end{tabular}


Table 2. Cont.

\begin{tabular}{|c|c|c|c|c|}
\hline Fermented Beverage & Microbiota & EPS & Beneficial Effects & References \\
\hline Aguamiel & $\begin{array}{c}\text { Acetobacter malorum, } \\
\text { Amycolatopsis orientalis; Bacillus *; } \\
\text { Candida; Clavispora; Diplobacter; } \\
\text { Hansenula; Kluyveromyces } \\
\text { marxianus var. bulgaricus; } \\
\text { Lactiplantibacillus plantarum *, } \\
\text { Lacticaseibacillus casei }{ }^{*} ; \\
\text { Leuconostoc, L. citreum }{ }^{*}, \text { L. } \\
\text { mesenteroides }{ }^{*} ; \\
\text { Companilactobacillus kimchii }{ }^{*} ; \\
\text { Mycoderma; Pichia }{ }^{*} \text { Pseudomonas; } \\
\text { Rhodotorula; Saccharomyces, S. } \\
\text { cerevisiae; Sarcina; Streptococcus; } \\
\text { Zymomonas mobilis. }\end{array}$ & $\begin{array}{c}\text { Dextran (Mw } 607 \mathrm{kDa} \text { composed } \\
\text { of D-glucopyranose) } \\
\text { Levan (Mw of } 568 \mathrm{kDa} \text { and } \\
<50 \mathrm{kDa}) \\
\text { Glucan (Mw } 94 \mathrm{kDa}) \\
\text { EPS (Mw } 66 \mathrm{kDa} \text { consisting of } \\
\text { xylose, glucose, and galactose) } \\
\text { EPS (Mw } 12.4 \mathrm{kDa} \text { consisting of } \\
\text { arabinose, rhamnose, fucose, } \\
\text { xylose, mannose, fructose, } \\
\text { galactose, and glucose) } \\
\text { EPS (Mw } 306 \text { kDa, containing } \\
\text { only one monosaccharide, } \\
\text { glucose) } \\
\text { HEP (Mw } 20 \mathrm{kDa} \text { with the } \\
\text { presence of monomers such as } \\
\text { glucan and mannose) } \\
\text { EPS (composed of a } \\
\text { phosphomannan core) } \\
\text { HEP (Mw } 1200 \mathrm{kDa} \text { composed of } \\
\text { four neural monosaccharides: } \\
\text { glucose, mannose, galactose, and } \\
\text { fucose) } \\
\text { HEP consists of glucose (75\%) } \\
\text { and rhamnose (15\%) }\end{array}$ & $\begin{array}{l}\text { Antibacterial } \\
\text { anticoagulant, } \\
\text { fibrinolytic activity, } \\
\text { prebiotic source, } \\
\text { thermophile, great } \\
\text { emulsification effect, } \\
\text { it could scavenge } \\
\text { superoxide anion } \\
\text { free radicals and im- } \\
\text { munomodulatory } \\
\text { activity }\end{array}$ & $\begin{array}{c}{[24,36,38-40,46,47,51,53,} \\
55,56,62,65,66]\end{array}$ \\
\hline
\end{tabular}

Species or genera with $\left(^{*}\right)$ on their right side means that those microorganisms are reported to produce EPS.

Next, Table 3 shows the EPS-produced microbiota related to tavern, tuba, sotol, and aguamiel.

Table 3. Reported EPS from tavern, tuba, sotol, and aguamiel microbiota.

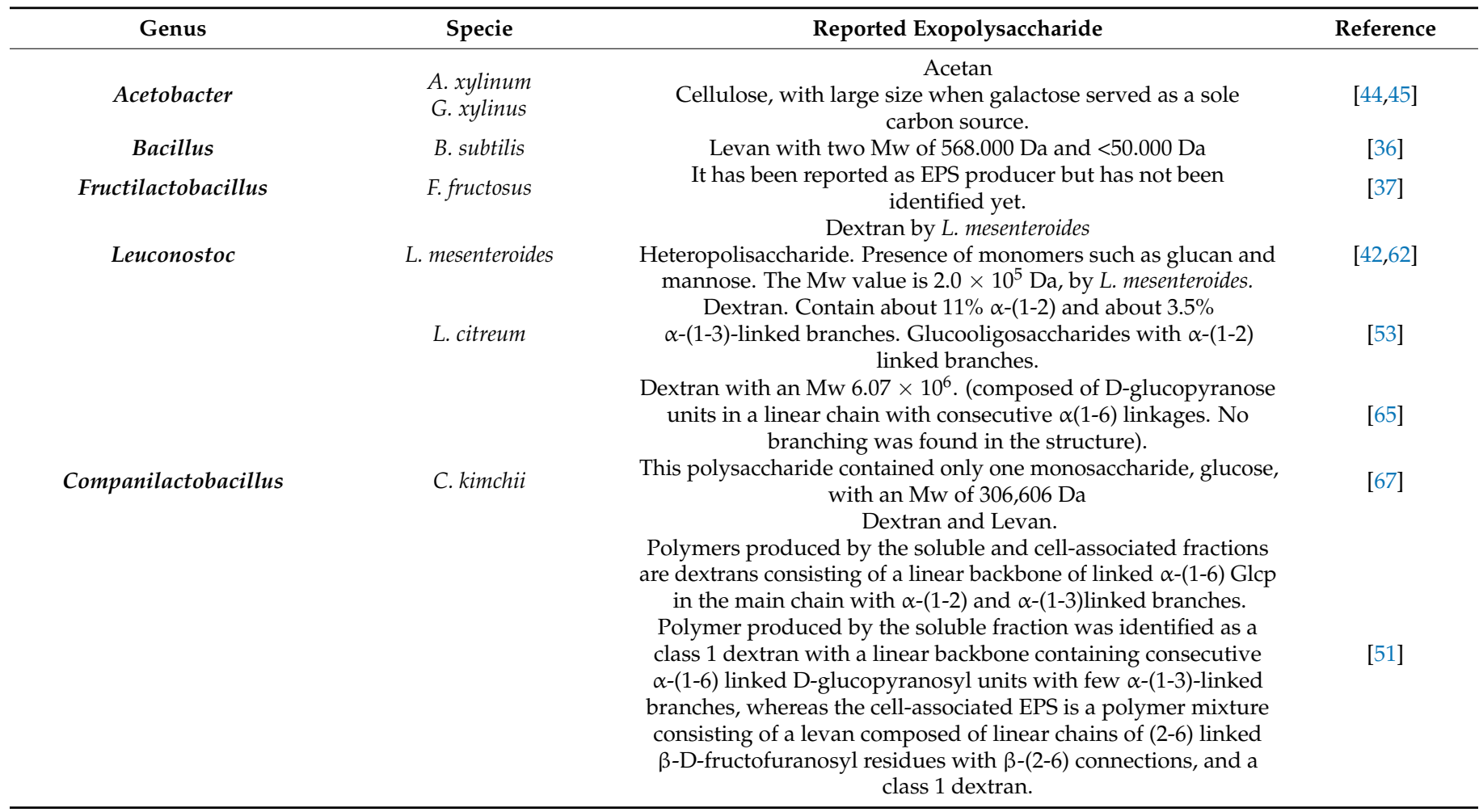


Table 3. Cont.

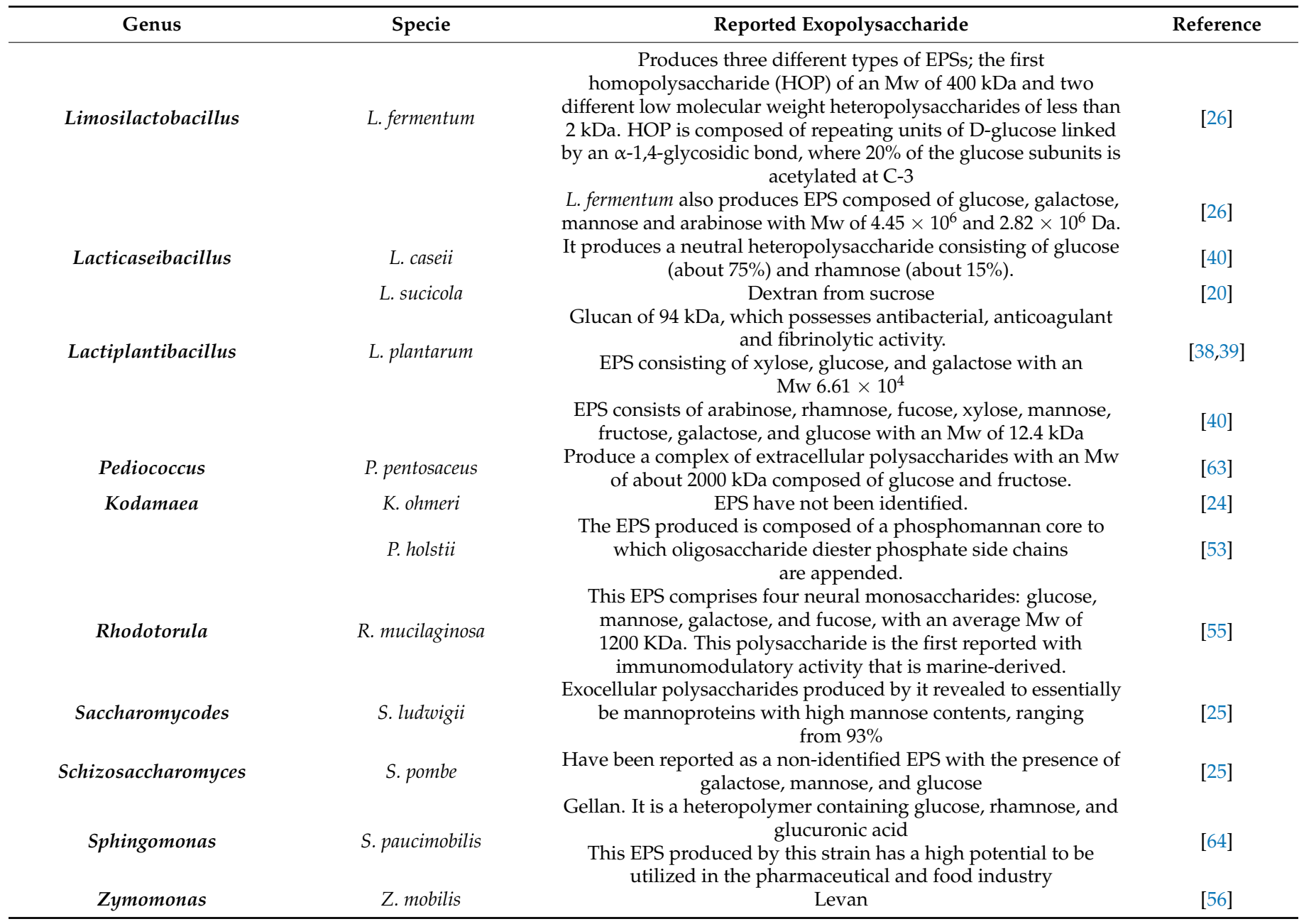

\section{Lactic Acid Bacteria and Their Influence on the Functional Qualities of Traditional Mexican Drinks}

LABs have a long history as fermentation initiators, contributing to a higher rate of hygienic safety, storage stability, improved rheology, and attractive sensory properties [11]. However, the EPS produced by LAB are regularly used as thickeners, stabilizers, and gelling agents due to their unique physicochemical properties in the food industry. At the same time, in some investigations, they are considered to be sustainable agents since the absorption of heavy metals through these polysaccharides has been reported [68].

In recent years, reported studies have shown that EPS confers potential benefits for the creation of healthy products, maintaining stability in the gastrointestinal environment, and improving the colonization of other probiotics. Due to this, EPS have tolerance to conditions that occur in the gastrointestinal tract (gastric acid and bile acids), allowing their permanence in the intestinal tract and the generation of short-chain fatty acids through the degradation of the colon [6,47]. Although the EPS that precede the LAB also show several beneficial activities for health, the most apparent health attribute imparted by EPSs is that of reducing the inclusion of sugars and fats associated with obesity. However, there are other important features: antioxidant activity, cholesterol level reduction, antimicrobial, antitumor, immunomodulation, antibiofilm, and antidiabetic formation [69]. Therefore, EPS from LAB could be used as functional additives in food production and have great potential for applications in the cosmetic and pharmaceutical industries due to their biological activities [69-71]. 
Traditionally, when talking about probiotics, most people refer to dairy products such as yogurt or cheese; however, the high demand of vegetarian and/or lactose intolerant consumers in search of healthy products has given rise to functional food production. According to what was reported by Heo et al., apple is a representative fruit tested in various processed foods, whether in jam, juice, or raw fruit. These have functional substances such as food fibers, vitamins, and polyphenols, placing them as specific agents in improving antioxidants, anticancer, antidiabetics, and good against cardiovascular diseases [72]. Given all of the benefits that apple can contribute, Heo et al., used this product as a raw material to elaborate a fermented apple juice, where an isolated strain of traditional fermented food from Korea was obtained: "Meju". This strain, belonging to LAB, was identified as L. plantarum [72]. The author used this LAB because some of the bacteria of this genus are acidophilic and can proliferate in the low $\mathrm{pH}$ that apple juice presents. In addition, $\mathrm{LAB}$ have been reported as probiotic strains that promote health and produce various metabolites that improve taste and reduce malic acid. At the end of the experiment, it was shown that the fermentation process that was conducted with apple juice together with $L$. plantarum, which presented synergistic activity since this achievement increases antidiabetic activity by more than $200 \%$ and almost $40 \%$ in terms of antioxidant activity when comparing the juice before and after fermentation. Heo et al. attributed antidiabetic activity to the presence of EPS since they can inhibit $\alpha$-glucosidase [72]. Thus, they can reduce blood sugar and delay the absorption of carbohydrates. This was demonstrated since producers and non-producers of EPS were used in the experiment, which aimed to determine the producing strain with the highest inhibitory activity [67].

On the other hand, Bancalari et al. elaborated functional juices from the direct fermentation of orange and celery juices through LAB with a prebiotic effect. Juices from fruits and vegetables are good alternatives since they meet dietary requirements and improve cardiovascular health [73]. However, to obtain safe juices with a long shelf life, it is necessary to stabilize them, the most frequent method for this being thermal treatments. Otherwise, using these technologies affects the nutritional value that these drinks offer by degrading the micronutrients and decreasing the content of vitamin $\mathrm{C}$, provitamin $\mathrm{A}$, and other dietary factors such as antioxidants and phytochemicals [74]. The solution that these authors found was lactic fermentation since it maintains or can even improve the nutritional and sensory properties of the product, the safety, and shelf life. LABs are widely known for the outstanding contribution of functional properties to fermented products. In this case, the presence of EPS reported by Lacticaseibacillus casei strains confer probiotic activity to the product; thus, a functional drink is obtained.

Bancalari et al. [73] evaluated fifty strains of LAB isolated from different dairy products, and 10 out of 50 strains were selected because they could grow in non-dairy products identified among those ten strains as Lacticaseibacillus casei, Lactobacillus rhamnosus, and Lacticaseibacillus paracasei. The resistance to bile salts, acidification performance as well as its EPS production were evaluated. Each of these strains was evaluated with both juices (orange and celery). As a result, it was found that no strain was able to produce EPS in orange juice. On the other hand, they presented good results in celery juice, where the L. rhamnosus strain showed the best values for EPS production. Nevertheless, it should be noted that the L. casei and L. rhamnosus strains obtained a good fermentation in both juices, opening a new perspective for dairy isolated strains as a starter in plant-derived juice fermentation, demonstrating the idea that adding probiotic strains to conduct the juice fermentation process could be an effective method to obtain a probiotic product, thus avoiding the use of heat treatments and maintaining its nutritional values [75-78].

Equally important, Pérez-Cataluña et al. [79] talks about sour atole, a Mexican acidic drink; this is a non-alcoholic drink derived from fermented corn. Sour atole is prepared by spontaneous fermentation for $24 \mathrm{~h}$, and bacteria such as LABs are commonly found at the end of this process. The author's objective was to analyze the microbial diversity present in this fermented drink, where strains from the Pediococcus, Weisella, Lactobacillus, and Leuconostoc genera were found. Genera such as Enterobacteriaceae, Lactobacillaceae, 
Leuconostocaceae, and Steptococcaceae with Acetobacteraceae for solid fermentation may be related to the high manual handling that the dough receives, while Enterobacteriaceae are found in the highest concentration and are necessary for the initial phase. LABs such as Lactobacillus were almost completely replaced after $12 \mathrm{~h}$ by the Streptococcus, Lactococcus, and Weisella genera during liquid fermentation.

On the other hand, in solid fermentation, the microorganism that prevailed throughout the whole process was Weisella, a dextran-producing homopolysaccharide that helps to improve the rheology of the beverage. Furthermore, as mentioned throughout this review, spontaneous fermentation helps improve technological functions because they confer organoleptic properties, which in many cases, contributes it to the production of EPS. Moreover, spontaneous fermentation helps give food functionality due to all of the biological activities that it can present thanks to the microbiota that is present during the entire process $[80,81]$.

\section{Final Remarks}

According to the reported literature, some of the species present in the microbiota described for each traditional Mexican beverage have been demonstrated to produce EPS $[82,83]$. These species were obtained through the fermentation process of each fermented beverage. It should be mentioned that most of them occur through spontaneous fermentation, where the proliferation of the microbiota that is present is naturally influenced by the geographical area in which the plant is located; factors such as humidity, temperature, and soil are important. Even so, the fauna and insects present in the area could interact with the plant during the fermentation process of the drink, resulting in different microorganisms that could contribute other properties. These microorganisms result in the produced drinking being a good source of beneficial effects to human health since it has been demonstrated that some EPS-producer strains possess biological effects such as antioxidant, prebiotic, and immunomodulatory activity, among others. However, several article reporting the use of EPS-producing LABs as starter strains exist. Due to their technological properties, they can be exploited in the food industry, as they permit the avoidance of certain treatments (physical and/or chemical) that are used to extend the shelf-life of the product, such as thickeners, stabilizers, and emulsifiers (this last one can also help to reduce the fat in food), with the added benefit that these can help maintain the nutritional properties of the products without needing to subject them to sudden treatments that increase the loss of these benefits. In particular, the organoleptic properties of some fermented beverages are related to the presence of EPS; for example, the viscosity texture in aguamiel can be attributed to the presence of dextran and levan polymers from Leuconostoc $[1,50,84]$.

Author Contributions: Conceptualization, A.C.F.-G. and R.R.-H.; data curation, M.L.C.-V., R.R.-H., and A.C.F.-G.; formal analysis, R.R.-H. and A.C.F.-G.; funding acquisition, A.C.F.-G.; investigation, M.L.C.-V., A.C.F.-G., J.F.S.-D. and A.S.-G.; methodology, M.L.C.-V. and A.C.F.-G.; supervision, A.C.F.G., R.R.-H., A.S.-G., J.C.C.-E. and J.F.S.-D.; writing-original draft, M.L.C.-V., R.R.-H., C.N.A.-G., A.S.-G., J.F.S.-D., J.C.C.-E. and A.C.F.-G.; writing-review and editing, M.L.C.-V., R.R.-H., J.F.S.-D. and A.C.F.-G. All authors have read and agreed to the published version of the manuscript.

Funding: This work was supported by the National Council for Science and Technology of Mexico (CONACYT) through project 316133. MLCV had financial support from the National Council for Science and Technology (CONACYT) of Mexico through a scholarship (1001727) to obtain an MSc in Science and Food Technology offered by the Department of Food Research of the Autonomous University of Coahuila.

Acknowledgments: The authors thank to National Council for Science and Technology (CONACYT) of Mexico for the research scholarship.

Conflicts of Interest: The authors declare no conflict of interest. 


\section{References}

1. Rana, S.; Upadhyay, L.S. Microbial Exopolysaccharides: Synthesis Pathways, Types and Their Commercial Applications. Int. J. Biol. Macromol. 2020, 157, 577-583. [CrossRef] [PubMed]

2. Chaisuwan, W.; Jantanasakulwong, K.; Wangtueai, S.; Phimolsiripol, Y.; Chaiyaso, T.; Techapun, C.; Phongthai, S.; You, S.G.; Regenstein, J.M.; Seesuriyachan, P. Microbial Exopolysaccharides for Immune Enhancement: Fermentation, Modifications and Bioactivities. Food Biosci. 2020, 35, 100564. [CrossRef]

3. Roselló-Soto, E.; Garcia, C.; Fessard, A.; Barba, F.; Munekata, P.; Lorenzo, J.; Remize, F. Nutritional and Microbiological Quality of Tiger Nut Tubers (Cyperus esculentus), Derived Plant-Based and Lactic Fermented Beverages. Fermentation 2018, 5, 3. [CrossRef]

4. Barcenilla, C.; Ducic, M.; López, M.; Prieto, M.; Álvarez-Ordóñez, A. Application of Lactic Acid Bacteria for the Biopreservation of Meat Products: A Systematic Review. Meat Sci. 2022, 183, 108661. [CrossRef]

5. Joshi, S.R.; Koijam, K. Exopolysaccharide Production by a Lactic Acid Bacteria, Leuconostoc Lactis Isolated from Ethnically Fermented Beverage. Natl. Acad. Sci. Lett. 2014, 37, 59-64. [CrossRef]

6. İspirli, H.; Demirbaş, F.; Dertli, E. Glucan Type Exopolysaccharide (EPS) Shows Prebiotic Effect and Reduces Syneresis in Chocolate Pudding. J. Food Sci. Technol. 2018, 55, 3821-3826. [CrossRef]

7. Welman, A.D. Exopolysaccharides from Fermented Dairy Products and Health Promotion. Adv. Fermented Foods Beverages 2015, 23-38.

8. García, C.; Rendueles, M.; Díaz, M. Liquid-Phase Food Fermentations with Microbial Consortia Involving Lactic Acid Bacteria: A Review. Food Res. Int. 2019, 119, 207-220. [CrossRef]

9. Rice, T.; Sahin, A.W.; Lynch, K.M.; Arendt, E.K.; Coffey, A. Isolation, Characterisation and Exploitation of Lactic Acid Bacteria Capable of Efficient Conversion of Sugars to Mannitol. Int. J. Food Microbiol. 2020, 321, 108546. [CrossRef]

10. Escobar-Ramírez, M.C.; Jaimez-Ordaz, J.; Escorza-Iglesias, V.A.; Rodríguez-Serrano, G.M.; Contreras-López, E.; Ramírez-Godínez, J.; Castañeda-Ovando, A.; Morales-Estrada, A.I.; Felix-Reyes, N.; González-Olivares, L.G. Lactobacillus Pentosus Abheau-05: An in Vitro Digestion Resistant Lactic Acid Bacterium Isolated from a Traditional Fermented Mexican Beverage. Rev. Argent. Microbiol. 2020, 52, 305-314. [CrossRef]

11. Gerwig, G.J. Structural Analysis of Exopolysaccharides from Lactic Acid Bacteria. Lact. Acid Bact. 2018, 67-84.

12. Ispirli, H.; Dertli, E. Isolation and Characterisation of Lactic Acid Bacteria from Traditional KOUMISS and Kurut. Int. J. Food Prop. 2017, 20 (Suppl. S3), S2441-S2449. [CrossRef]

13. Lynch, K.M.; Zannini, E.; Coffey, A.; Arendt, E.K. Lactic Acid Bacteria Exopolysaccharides in Foods and Beverages: Isolation, Properties, Characterization, and Health Benefits. Annu. Rev. Food Sci. Technol. 2018, 9, 155-176. [CrossRef]

14. Zhang, G.; Zhang, W.; Sun, L.; Sadiq, F.A.; Yang, Y.; Gao, J.; Sang, Y. Preparation Screening, Production Optimization and Characterization of Exopolysaccharides Produced by Lactobacillus Sanfranciscensis LS-1001 Isolated from Chinese Traditional Sourdough. Int. J. Biol. Macromol. 2019, 139, 1295-1303. [CrossRef]

15. Bajpai, V.K.; Rather, I.A.; Majumder, R.; Shukla, S.; Aeron, A.; Kim, K.; Kang, S.C.; Dubey, R.C.; Maheshwari, D.K.; Lim, J.; et al. Exopolysaccharide and Lactic Acid Bacteria: Perception, Functionality and Prospects. Bangladesh J. Pharmacol. $2015,11,1$. [CrossRef]

16. Hooshdar, P.; Khosravi-Darani, K.; Ghadam, P.; Kermanshahi, R.K. A Review on Production of Exopolysaccharide and Biofilm in Probiotics like Lactobacilli and Methods of Analysis. Biointerface Res. Appl. Chem. 2020, 10, 6058-6075.

17. Nouha, K.; Kumar, R.S.; Balasubramanian, S.; Tyagi, R.D. Critical Review of EPS Production, Synthesis and Composition for Sludge Flocculation. J. Environ. Sci. 2018, 66, 225-245. [CrossRef]

18. Korcz, E.; Varga, L. Exopolysaccharides from Lactic Acid Bacteria: Techno-Functional Application in the Food Industry. Trends Food Sci. Technol. 2021, 110, 375-384. [CrossRef]

19. Xu, Y.; Cui, Y.; Yue, F.; Liu, L.; Shan, Y.; Liu, B.; Zhou, Y.; Lü, X. Exopolysaccharides Produced by Lactic Acid Bacteria and Bifidobacteria: Structures, Physiochemical Functions and Applications in the Food Industry. Food Hydrocoll. 2019, 94, 475-499. [CrossRef]

20. Coutiño, B.; Flores, A.C.; Vela-Gutiérrez, G.; Sepúlveda, L.; Aguilar, C.N.; Chavez-Gonzalez, M.; Rodríguez, R. Tavern or Coyol Wine: A Beverage from Palm Sap with Biotechnological Potential. Biotechnol. Prog. Beverage Consum. 2020, $233-252$.

21. Coutiño, B.; Rodríguez, R.; Belmares, R.; Aguilar, C.N.; Ruelas, X. Selección de la bebida "Taberna" obtenida de la palma Acrocomia aculeata y análisis químico proximal. Multiciencias 2015, 15, 397-409.

22. Santiago-Urbina, J.A.; Verdugo-Valdez, A.G.; Ruiz-Terán, F. Physicochemical and Microbiological Changes during Tapping of Palm Sap to Produce an Alcoholic Beverage Called "Taberna", Which Is Produced in the South East of Mexico. Food Control 2013, 33, 58-62. [CrossRef]

23. Alcántara-Hernández, R.J.; Rodríguez-Álvarez, J.A.; Valenzuela-Encinas, C.; Gutiérrez-Miceli, F.A.; Castañón-González, H.; Marsch, R.; Ayora-Talavera, T.; Dendooven, L. The Bacterial Community in 'Taberna' a Traditional Beverage of Southern Mexico. Lett. Appl. Microbiol. 2010, 51, 558-563. [CrossRef]

24. Song, J.-O.; Kim, T.-J.; Kim, Y.-H. Inhibitory Effect on Rotavirus by Exopolysaccharides Extracted from Kefir. Korean J. Food Sci. Anim. Resour. 2007, 27, 538-542. [CrossRef]

25. Giovani, G.; Rosi, I.; Bertuccioli, M. Quantification and Characterization of Cell Wall Polysaccharides Released by NonSaccharomyces Yeast Strains during Alcoholic Fermentation. Int. J. Food Microbiol. 2012, 160, 113-118. [CrossRef] 
26. Wang, K.; Niu, M.; Song, D.; Song, X.; Zhao, J.; Wu, Y.; Lu, B.; Niu, G. Preparation, Partial Characterization and Biological Activity of Exopolysaccharides Produced from Lactobacillus Fermentum S1. J. Biosci. Bioeng. 2020, 129, 206-214. [CrossRef]

27. Pérez-Armendáriz, B.; Cardoso-Ugarte, G.A. Traditional Fermented Beverages in Mexico: Biotechnological, Nutritional, and Functional Approaches. Food Res. Int. 2020, 136, 109307. [CrossRef]

28. Flores-Gallegos, A.C.; Vázquez-Vuelvas, O.F.; López-López, L.L.; Sainz-Galindo, A.; Ascacio-Valdes, J.A.; Aguilar, C.N.; Rodriguez-Herrera, R. Tuba: A Fermented and Refreshing Beverage from Coconut Palm Sap. Non-Alcohol. Beverages 2019, 163-184.

29. Bhat, B.; Bajaj, B.K. Hypocholesterolemic Potential and Bioactivity Spectrum of an Exopolysaccharide from a Probiotic Isolate Lactobacillus Paracasei M7. Bioact. Carbohydr. Diet. Fibre 2019, 19, 100191. [CrossRef]

30. La China, S.; Zanichelli, G.; De Vero, L.; Gullo, M. Oxidative Fermentations and Exopolysaccharides Production by Acetic Acid Bacteria: A Mini Review. Biotechnol. Lett. 2018, 40, 1289-1302. [CrossRef]

31. Wang, Q.; Huang, Q.; Liang, L.; Zhang, L.; Ping, Z.; Hu, B.; Ma, N. Research on Sugarcane Juice Fermentation by Ganoderma Lucidum and Assay of Antioxidant Activity of Exopolysaccharide. J. Food Process. Preserv. 2018, 42, 1-8. [CrossRef]

32. Ionela Istrati, D.; Mihaela Pricop, E.; Georgiana Profir, A.; Vizireanu, C. Fermented Functional Beverages. In Functional Foods; IntechOpen: London, UK, 2019.

33. Flores-Gallegos, A.C.; Cruz-Requena, M.; Castillo-Reyes, F.; Rutiaga-Quiñones, O.M.; Torre, L.S.; Paredes-Ortíz, A.; Soto, O.N.; Rodriguez-Herrera, R. Sotol, an Alcoholic Beverage with Rising Importance in the Worldwide Commerce. In Alcoholic Beverages; Woodhead Publishing: Sawston, UK, 2019; pp. 141-160.

34. Atputharajah, J.D.; Widanapathirana, S.; Samarajeewa, U. Microbiology and Biochemistry of Natural Fermentation of Coconut Palm Sap. Food Microbiol. 1986, 3, 273-280. [CrossRef]

35. Kalaiyarasi, K.; Sangeetha, K.; Rajarajan, S. A comparative study on the microbial flora of the fresh sap from cut inflorescence and fermented sap (toddy) of Borrassus flabellifer Linn (Palmyrah tree) and of Cocos nucifera Linn (Coconut tree) to identify the microbial fermenters. Int. J. Res. Pure Appl. Microbiol. 2013, 3, 43-47.

36. Dos Santos, L.F.; De Melo, F.B.C.; Paiva, W.M.; Borsato, D.; Da Silva, M.C.C.; Celligoi, M.P.C. Characterization and optimization of levan production by Bacillus subtilis NATTO. Rom. Biotechnol. Lett. 2013, 18, 8413-8422.

37. Ma'unatin, A.; Harijono, H.; Zubaidah, E.; Rifa'i, M. The isolation of exopolysaccharide-producing lactic acid bacteria from lontar (Borassus flabellifer L.) sap. Iran. J. Microbiol. 2020, 12, 437-444. [CrossRef]

38. Abo Saif, F.A.A.; Sakr, E.A.E. Characterization and Bioactivities of Exopolysaccharide Produced from Probiotic Lactobacillus Plantarum 47fe and Lactobacillus Pentosus 68fe. Bioact. Carbohydr. Diet. Fibre 2020, 24, 100231. [CrossRef]

39. Liu, Z.; Zhang, Z.; Qiu, L.; Zhang, F.; Xu, X.; Wei, H.; Tao, X. Characterization and Bioactivities of the Exopolysaccharide from a Probiotic Strain of Lactobacillus Plantarum WLPL04. J. Dairy Sci. 2017, 100, 6895-6905. [CrossRef]

40. Min, W.-H.; Fang, X.-B.; Wu, T.; Fang, L.; Liu, C.-L.; Wang, J. Characterization and Antioxidant Activity of an Acidic Exopolysaccharide from Lactobacillus Plantarum JLAU103. J. Biosci. Bioeng. 2019, 127, 758-766. [CrossRef]

41. Li, Y.; Liu, Y.; Cao, C.; Zhu, X.Y.; Wang, C.; Wu, R.; Wu, J. Extraction and Biological Activity of Exopolysaccharide Produced by Leuconostoc Mesenteroides Sn-8. Int. J. Biol. Macromol. 2020, 157, 36-44. [CrossRef]

42. Fang, L.; Catchmark, J.M. Characterization of Cellulose and Other Exopolysaccharides Produced from Gluconacetobacter Strains. Carbohydr. Polym. 2015, 115, 663-669. [CrossRef]

43. Ramírez-Guzmán, K.N.; Torres-León, C.; Martinez-Medina, G.A.; de la Rosa, O.; Hernández-Almanza, A.; Alvarez-Perez, O.B.; Araujo, R.; González, L.R.; Londoño, L.; Ventura, J.; et al. Traditional Fermented Beverages in Mexico. In Fermented Beverages; Woodhead Publishing: Sawston, UK, 2019; pp. 605-635.

44. Jansson, P.-E.; Lindberg, J.; Wimalasiri, K.M.S.; Dankert, M.A. Structural Studies of Acetan, an Exopolysaccharide Elaborated by Acetobacter Xylinum. Carbohydr. Res. 1993, 245, 303-310. [CrossRef]

45. Fang, L.; Catchmark, J.M. Characterization of Exopolysaccharides from Certain Strains of Gluconacetobacter Xylinus. In Proceedings of the American Society of Agricultural and Biological Engineers Annual International Meeting, Louisville, KY, USA, 7-10 August 2011; p. 1111152.

46. Villarreal-Morales, S.L.; Muñiz-Márquez, D.B.; Michel-Michel, M.; González-Montemayor, Á.-M.; Escobedo-García, S.; SalasTovar, J.A.; Flores-Gallegos, A.C.; Rodríguez-Herrera, R. Aguamiel a Fresh Beverage from Agave Spp. SAP with Functional Properties. In Nature Beverages; Academic Press: Cambridge, MA, USA, 2019; pp. 179-208.

47. Cervantes-Elizarrarás, A.; Cruz-Cansino, N.; Ramírez-Moreno, E.; Vega-Sánchez, V.; Velázquez-Guadarrama, N.; Zafra-Rojas, Q.; Piloni-Martini, J. In Vitro Probiotic Potential of Lactic Acid Bacteria Isolated from Aguamiel and Pulque and Antibacterial Activity against Pathogens. Appl. Sci. 2019, 9, 601. [CrossRef]

48. Ortiz-Basurto, R.I.; Pourcelly, G.; Doco, T.; Williams, P.; Dornier, M.; Belleville, M.-P. Analysis of the Main Components of the Aguamiel Produced by the Maguey-Pulquero (Agave mapisaga) throughout the Harvest Period. J. Agric. Food Chem. 2008, 56, 3682-3687. [CrossRef]

49. Escobedo-García, S.; Salas-Tovar, J.A.; Flores-Gallegos, A.C.; Contreras-Esquivel, J.C.; González-Montemayor, Á.M.; López, M.G.; Rodríguez-Herrera, R. Functionality of Agave Bagasse as Supplement for the Development of Prebiotics-Enriched Foods. Plant Foods Hum. Nutr. 2019, 75, 96-102. [CrossRef] 
50. Huang, M.L.; Huang, J.Y.; Kao, C.Y.; Fang, T.J. Fermented Soymilk and Soy and Cow Milk Mixture, Supplemented with Orange Peel Fiber Ortremella Flavafermented Powder as Prebiotics for High Exopolysaccharide-Producinglactobacillus Pentosus SLC 13. J. Sci. Food Agric. 2019, 99, 4373-4382. [CrossRef]

51. Torres-Rodríguez, I.; Rodríguez-Alegría, M.E.; Miranda-Molina, A.; Giles-Gómez, M.; Conca Morales, R.; López-Munguía, A.; Bolívar, F.; Escalante, A. Screening and Characterization of Extracellular Polysaccharides Produced by Leuconostoc kimchii Isolated from Traditional Fermented Pulque Beverage. SpringerPlus 2014, 3, 583. [CrossRef]

52. Castro-Rodríguez, D.; Hernández-Sánchez, H.; Yáñez Fernández, J. Structural Characterization and Rheological Properties of Dextran Produced by Native Strains Isolated of Agave Salmiana. Food Hydrocoll. 2019, 90, 1-8.

53. Maina, N.H.; Tenkanen, M.; Maaheimo, H.; Juvonen, R.; Virkki, L. NMR Spectroscopic Analysis of Exopolysaccharides Produced by Leuconostoc citreum and Weissella confusa. Carbohydr. Res. 2008, 343, 1446-1455. [CrossRef]

54. Parolis, L.A.S.; Parolis, H.; Kenne, L.; Meldal, M.; Bock, K. The Extracellular Polysaccharide of Pichia (Hansenula) Holstii NRRL Y-2448: The Phosphorylated Side Chains. Carbohydr. Res. 1998, 309, 77-87. [CrossRef]

55. Li, H.; Huang, L.; Zhang, Y.; Yan, Y. Production, Characterization and Immunomodulatory Activity of an Extracellular Polysaccharide from Rhodotorula Mucilaginosa YL-1 Isolated from Sea Salt Field. Mar. Drugs 2020, 18, 595. [CrossRef]

56. Ernandes, F.M.; Cruz, C.H. Uso De Caldo De Cana-De-Açúcar Para Produção De Levana Por Zymomonas Mobilis CCT4494. Ciênc. Agrotecnol. 2011, 35, 354-360. [CrossRef]

57. Marsh, A.J.; Hill, C.; Ross, R.P.; Cotter, P.D. Fermented Beverages with Health-Promoting Potential: Past and Future Perspectives. Trends Food Sci. Technol. 2014, 38, 113-124. [CrossRef]

58. Hittinger, C.T.; Steele, J.L.; Ryder, D.S. Diverse Yeasts for Diverse Fermented Beverages and Foods. Curr. Opin. Biotechnol. 2018, 49, 199-206. [CrossRef]

59. Kaur, P.; Ghoshal, G.; Banerjee, U.C. Traditional Bio-Preservation in Beverages: Fermented Beverages. Preserv. Preserv. Approaches Beverages 2019, 69-113.

60. Ordóñez, J.L.; Troncoso, A.M.; García-Parrilla, M.D.; Callejón, R.M. Recent Trends in the Determination of Biogenic Amines in Fermented Beverages-A Review. Anal. Chim. Acta 2016, 939, 10-25. [CrossRef]

61. Astudillo-Melgar, F.; Ochoa-Leyva, A.; Utrilla, J.; Huerta-Beristain, G. Bacterial Diversity and Population Dynamics during the Fermentation of Palm Wine from Guerrero Mexico. Front. Microbiol. 2019, 10, 531. [CrossRef]

62. Leathers, T.D.; Côté, G.L. Biofilm Formation by Exopolysaccharide Mutants of Leuconostoc mesenteroides Strain NRRL B-1355. Appl. Microbiol. Biotechnol. 2008, 78, 1025-1031. [CrossRef]

63. Semjonovs, P.; Zikmanis, P. Evaluation of Novel Lactose-Positive and Exopolysaccharide-Producing Strain of Pediococcus pentosaceus for Fermented Foods. Eur. Food Res. Technol. 2007, 227, 851-856. [CrossRef]

64. Soumiya, S.; Santhiagu, A.; Manjusha Chemmattu, M. Optimization of Cultural Conditions of Gellan Gum Production from Recombinant Sphingomonas paucimobilis ATCC 31461 and Its Characterization. J. Appl. Biol. Biotechnol. 2021, 9, 58-67.

65. Yang, Y.; Feng, F.; Zhou, Q.; Zhao, F.; Du, R.; Zhou, Z.; Han, Y. Isolation, Purification, and Characterization of Exopolysaccharide Produced by Leuconostoc Citreum N21 from Dried Milk Cake. Trans. Tianjin Univ. 2018, 25, 161-168. [CrossRef]

66. Kim, H.J.; Chang, H.C. Isolation and characterization of exopolysaccharide producing lactic acid bacteria from kimchi. Korean J. Microbiol. Biotechnol. 2006, 34, 196-203.

67. Oh, Y.J.; Jung, D.S. Evaluation of Probiotic Properties of Lactobacillus and Pediococcus Strains Isolated from Omegisool, a Traditionally Fermented Millet Alcoholic Beverage in Korea. LWT-Food Sci. Technol. 2015, 63, 437-444. [CrossRef]

68. Zhao, D.; Jiang, J.; Du, R.; Guo, S.; Ping, W.; Ling, H.; Ge, J. Purification and Characterization of an Exopolysaccharide from Leuconostoc Lactis L2. Int. J. Biol. Macromol. 2019, 139, 1224-1231. [CrossRef]

69. Liu, T.; Zhou, K.; Yin, S.; Liu, S.; Zhu, Y.; Yang, Y.; Wang, C. Purification and Characterization of an Exopolysaccharide Produced by Lactobacillus Plantarum Hy Isolated from Home-Made Sichuan Pickle. Int. J. Biol. Macromol. 2019, 134, 516-526. [CrossRef]

70. Lynch, K.M.; Coffey, A.; Arendt, E.K. Exopolysaccharide Producing Lactic Acid Bacteria: Their Techno-Functional Role and Potential Application in Gluten-Free Bread Products. Food Res. Int. 2018, 110, 52-61. [CrossRef] [PubMed]

71. Bhunia, B.; Prasad Uday, U.S.; Oinam, G.; Mondal, A.; Bandyopadhyay, T.K.; Tiwari, O.N. Characterization, Genetic Regulation and Production of Cyanobacterial Exopolysaccharides and Its Applicability for Heavy Metal Removal. Carbohydr. Polym. 2018, 179, 228-243. [CrossRef] [PubMed]

72. Heo, J.; Park, H.-S.; Uhm, T.-B. Production of Fermented Apple Juice Using Lactobacillus Plantarum JBE245 Isolated from Korean Traditional Meju. Korean J. Food Sci. Technol. 2016, 48, 445-453. [CrossRef]

73. Bancalari, E.; Castellone, V.; Bottari, B.; Gatti, M. Wild Lactobacillus Casei Group Strains: Potentiality to Ferment Plant Derived Juices. Foods 2020, 9, 314. [CrossRef]

74. Torres, S.; Verón, H.; Contreras, L.; Isla, M.I. An Overview of Plant-Autochthonous Microorganisms and Fermented Vegetable Foods. Food Sci. Hum. Wellness 2020, 9, 112-123. [CrossRef]

75. Mitra, S.; Ghosh, B.C. Quality Characteristics of Kefir as a Carrier for Probiotic Lactobacillus Rhamnosus GG. Int. J. Dairy Technol. 2019, 73, 384-391. [CrossRef]

76. Mituniewicz-Małek, A.; Zielińska, D.; Ziarno, M. Probiotic Monocultures in Fermented Goat Milk Beverages—Sensory Quality of Final Product. Int. J. Dairy Technol. 2019, 72, 240-247. [CrossRef] 
77. Grom, L.C.; Coutinho, N.M.; Guimarães, J.T.; Balthazar, C.F.; Silva, R.; Rocha, R.S.; Freitas, M.Q.; Duarte, M.C.; Pimentel, T.C.; Esmerino, E.A.; et al. Probiotic Dairy Foods and Postprandial Glycemia: A Mini-Review. Trends Food Sci. Technol. 2020, 101, 165-171. [CrossRef]

78. Roobab, U.; Batool, Z.; Manzoor, M.F.; Shabbir, M.A.; Khan, M.R.; Aadil, R.M. Sources, Formulations, Advanced Delivery and Health Benefits of Probiotics. Curr. Opin. Food Sci. 2020, 32, 17-28. [CrossRef]

79. Pérez-Cataluña, A.; Elizaquível, P.; Carrasco, P.; Espinosa, J.; Reyes, D.; Wacher, C.; Aznar, R. Diversity and Dynamics of Lactic Acid Bacteria in Atole Agrio, a Traditional Maize-Based Fermented Beverage from South-Eastern Mexico, Analysed by High Throughput Sequencing and Culturing. Antonie Leeuwenhoek 2017, 111, 385-399. [CrossRef]

80. Chiou, T.-Y.; Suda, W.; Oshima, K.; Hattori, M.; Matsuzaki, C.; Yamamoto, K.; Takahashi, T. Lactobacillus Kosoi Sp. Nov., a Fructophilic Species Isolated from Kôso, a Japanese Sugar-Vegetable Fermented Beverage. Antonie Leeuwenhoek 2018, 111, 1149-1156. [CrossRef]

81. Adesulu-Dahunsi, A.T.; Dahunsi, S.O.; Olayanju, A. Synergistic Microbial Interactions between Lactic Acid Bacteria and Yeasts during Production of Nigerian Indigenous Fermented Foods and Beverages. Food Control 2020, 110, 106963. [CrossRef]

82. Ripari, V. Techno-Functional Role of Exopolysaccharides in Cereal-Based, Yogurt-like Beverages. Beverages 2019, 5, 16. [CrossRef]

83. Lorusso, A.; Coda, R.; Montemurro, M.; Rizzello, C. Use of Selected Lactic Acid Bacteria and Quinoa Flour for Manufacturing Novel Yogurt-like Beverages. Foods 2018, 7, 51. [CrossRef]

84. Llamas-Arriba, M.G.; Hernández-Alcántara, A.M.; Yépez, A.; Aznar, R.; Dueñas, M.T.; López, P. Functional and Nutritious Beverages Produced by Lactic Acid Bacteria. Nutr. Beverages 2019, 419-465. 